\title{
THE IMPACT OF INSTITUTIONAL FACTORS ON FOREIGN DIRECT INVESTMENT INFLOWS: CROSS-COUNTRY ANALYSIS

\author{
Rogneda Groznykh ${ }^{1}$, Igor Drapkin ${ }^{2}$, Oleg Mariev ${ }^{3,4}$
}

\begin{abstract}
This research paper is devoted to analysis of various institutional factors as determinants of foreign direct investment (further - FDI) inflows to different countries. The objective of the research is to estimate the effect of institutions on FDI inflows. The analysis is provided on a database of cross-country FDI inflows on 72 countries FDI-importers and 112 countries FDI-exporters in the period from 2001 to 2016. It is supposed in the paper that the impact of institutional factors might be different for the groups of developed and developing countries; since developed economies have higher institutional indicators, they tend to attract larger amounts of foreign direct investment compared to developing economies, where institutional development is at the lower level. The estimation is based on the gravity approach, which considers the positive effects of countries' GDP and the negative effect of the distance between them. The main method used for the econometric estimation is the Pseudo Poisson Maximum Likelihood (PPML) regression, which is considered to be one of the adequate methods for estimating such data. During the research the problems of zero-observations and correlation between institutional indicators are solved. The results have shown that higher quality of institutions tends to attract more foreign direct investment to a country. Thus, institutions in developed countries have positive and significant impact on FDI attraction. At the same time, the analysis of developing countries has shown that some institutions have less significant influence on the FDI inflows. Based on the results of the research, possible recommendations for government policy on institutional improvement can be suggested.
\end{abstract}

JEL Classification Numbers: F21, DOI: 10.12955/cbup.v7.1348

Keywords: foreign direct investment, institutional environment, gravity model, Pseudo Poisson Maximum Likelihood method, political stability, corruption

\section{Introduction}

Currently, foreign direct investment (FDI) is becoming more significant by being one of the factors of sustainable, qualitative and balanced development of the country through technological modernization and development, improvement of management, provision of workplaces etc. The institutional environment is one of the key factors that influence FDI attraction. In the current political situation investors tend to search countries with more developed institutions, which can guarantee the reservation of their rights and security of their assets. That means that countries with more developed institutions attract larger volumes of foreign direct investment. Thus, the problem of identifying institutional factors, which influence foreign direct investment inflows, is of great importance, especially for developing economies, where institutional development is considered to be at the lower level. Besides, the analysis of institutional factors, that have greater impact on the volumes of FDI might provide a possibility to work out recommendations for institutional government policy improvement.

Therefore, the main goal of the paper is to reveal and estimate the effect of various institutional factors on volumes of FDI inflows. Additionally, we estimate this effect separately for developed and developing countries in order to compare the significance of institutional factors on FDI inflows and define, which economies are more successful in FDI attraction. For the purpose, six different institutional indicators are used in the econometric estimation. The indexes are estimated by PRSGroup (Political Risk Services Group). An econometric model is constructed based on the gravity approach. The dependent variable is bilateral FDI inflows. An econometric estimation is conducted using the Pseudo Poisson Maximum Likelihood method. The analysis is provided for all countries and separately for developed and developing economies.

\section{Literature Review}

The influence of institutions on the foreign direct investment inflows is actively discussed by researchers. However, the main works have appeared only in the second half of the twentieth century.

\footnotetext{
${ }^{1}$ Graduate School of Economics and Management, Ural Federal University, Ekaterinburg, Russian Federation, ronav999@gmail.com

${ }^{2}$ Graduate School of Economics and Management, Ural Federal University, Ekaterinburg, Russian Federation, i.m.drapkin@mail.ru

${ }^{3}$ Graduate School of Economics and Management, Ural Federal University; Ekaterinburg, Russian Federation, o.s.mariev@urfu.ru

${ }^{4}$ The Ural branch of Russian Academy of Sciences, Ekaterinburg, Russian Federation, o.s.mariev@urfu.ru
} 
Most of them have been devoted to the estimation of the political instability and corruption level impact on FDI inflows. Later research includes a broader variety of institutional factors.

How to measure institutions

The main problem, that researchers usually meet, is that institutions are qualitative indicators that do not have any generally accepted measure. Thus, institutions can be indicated as quantitative indicators such as number of revolutions, number of crimes, amount of reforms, liberalization etc. (Bevan et al., 2004). The main disadvantage of such measurement is the lack of statistics among the countries. Thus, proxy-variables of institutions were introduced by the researchers. For example, Knack and Keefer in their study of institutional impact on results of economic activity use indexes estimated by rating agencies and conclude that proxy-variables are more representative compared to quantitative ones. According to the authors, such indicators as the number of revolutions or assassinations are not considered to be very indicative, because in some countries there could be no revolutions or attacks in the researched period. As a result of the research the authors conclude that all institutional indicators positively affect both FDI and economic growth (Knack and Keefer, 1995).

In addition, aggregate indexes can be used as institution measurements: for example, the index of economic freedom (Tintin, 2013), or the International Country Risk Guide (ICRG) index (Ali et al., 2010). However, such indexes give the possibility to estimate only aggregate impact of institutions. However, according to methodology of ICRG rating estimation, the rating comprises 22 political, financial and economic variables (The PRS Group, 2018). These subcomponents can be extracted and used to estimate effects of different institutional indicators on FDI inflows (Kolstad and Tondel, 2002).

Empirical analysis of institutions and their impact on FDI

One of the main works on the topic of interrelation of FDI and institutions was provided by Brunetti and Weder (1998). According to their research, instability or ambiguousness of institutional structure is a negative factor that lowers the amount of foreign direct investment inflows (Brunetti and Weder, 1998). The analysis is provided based on the data for 60 countries from 1974 to 1989 . The authors estimate the influence of institutional factors on investment ratings of developing countries. For this purpose, they divide factors into four different groups:

- Indicators of government instability: amount of revolutions, military coups, political demonstrations and probability of power change;

- Indicators of political violence: amount of assassinations, strikes, military attacks and deaths in political conflicts;

- Instability of institutional environment: black market profit deviation, inflation and Constitutional reforms;

- Indicators of instability increase: insecurity of the legislation system, bureaucracy quality, corruption and rule of law.

The results have proved that the tested indicators negatively affect FDI inflows. However, they also conclude that further improvement of institutions tends to increase the amount of FDI inflows.

Another study on the problem of the impact of institutional development on foreign direct investment inflows was provided by Kolstadt and Tondel (Kolstadt and Tondel, 2002). First, they define the main macroeconomic factors that influence FDI inflows, such as market size, economic growth rates, openness, infrastructure, macroeconomic stability, exchange rate, distance between country-importer of FDI and country-exporter. The authors analyze data on 61 countries from 1989 to 2000 . For the institutional indicators the authors use subcomponents of ICRG index provided by the PRS Group. The authors also mention that all institutional factors are highly correlated with each other. In order to avoid this multicollinearity, they first run regressions with control variables and one institutional factor. Afterwards, they divide all factors into three groups and add into the regression one factor from each group. In the result, the authors conclude that political stability, lower amount of internal and ethnic conflicts have significant positive impact on FDI inflows. At the same time the level of corruption have significant negative impacts on FDI inflows. Other variables appeared to be insignificant (Kolstadt and Tondel, 2002).

With increasing interest towards the institutional effect on foreign direct investment, more works have appeared during the last decade. For example, in 2005, the Hamburg Institute of International 
Economics has provided research on political risk and institution and their impact on foreign direct investment. The research is also based on the indicators provided by the PRS Group, because they reflect all the political and social institutions. Additionally, authors include macroeconomic control variables. In conclusion authors point out that investment profile, internal and external conflicts, ethnic tensions and democratic accountability are the main factors that have significant and positive impact on the FDI attraction in a host economy (Busse and Hefker, 2005). Another study on the same period was conducted by CEPII (Center for research and expertise on the world economy). The aim of the authors was to define the main determinants of foreign direct investment bilateral flows using a gravity approach. The authors analyzed data on 52 countries based on the Institutional Profiles database. The analysis showed that most of the institutional determinants have significant and positive impact on FDI inflows except capital concentration and rule of law (Benassy-Quere et al., 2007). Daude and Stein in their research used six aggregate indicators that are subcomponents of the ICRG index (Daude and Stein, 2007): Voice and Accountability, Political Stability and Lack of Violence, Government Effectiveness, Regulatory Quality, Rule of Law, and Control of Corruption. The authors conclude that all institutions have positive significant impact on FDI except Voice and Accountability. Nowadays the aspect of institutional factors and the effect on inward foreign direct investment is of great interest, especially for developing economies. For example, Peres et al. (2018) consider in their study how institutional quality affects foreign direct investment inflows to developed and developing countries. The research is based on data from 110 countries in the period from 2002 till 2012. The results of the research confirm the hypothesis that more developed countries are more successful in attracting FDI due to institutions with a higher quality. In addition, the most significant factors appeared to be "corruption" and "rule of law" (Peres et al., 2018). In the research on FDI attractiveness and institutional factors, N. Bailey confirms the theory that institutional factors, indicating political stability, democracy level, secure of rights promote foreign direct investment inflows, while corruption, military conflicts and cultural difference deter it (Bailey, 2018).

\section{Methodology}

The research presented in the current paper is based on the gravity approach, which first was implemented by Tinbergen (1962) for international trade flows. In 1997 Brainard (1997) applied the method to estimate foreign direct investment flows. The same gravity approach was also used by Silva and Tenreyro (Silva S., 2006) and in previous studies of the authors (Mariev, 2016). The basic model can be written as follows:

$$
F D I_{i j t}=\frac{G D P_{i} G D P_{j}}{\text { Dist }_{i j}}
$$

where $F D I_{i j t}$ is foreign direct investment flow from country i to country $\mathrm{j}$ in the time t, $G D P_{i}$ and $G D P_{j}$ indicate the size of the economies and $D_{i s t} t_{i j}$ is distance between the countries.

The model is considered to give precise results of the estimations. The main assumptions of the gravity model is that the size of the market in a host-country and a home-country of FDI positively affects the amount of bilateral foreign direct investment flows, while the distance between two countries has negative impact on bilateral FDI flows.

The main econometric method used for the estimation is Pseudo Poisson Maximum Likelihood method, which considers a non-linear form of the gravity model:

$$
y_{i}=\exp \left(x_{i} \beta\right)+\varepsilon_{i},
$$

which was first proposed by Silva and Tenreyro for gravity model estimation (Silva S., 2006). 'This method solves all the main problems appearing during gravity model estimation, such as heteroscedasticity and biasness. The PPML method provides unbiased and consistent estimation, for what is considered to be the most optimal and relevant. The only disadvantage of the method is that it considers only positive values of a dependent variable that reduces the amount of observations in the regression. Therefore, we generate a new variable FDI+1 by adding 1 to all values. That gives a possibility to consider more observations by econometric analysis and does not distort the estimations, because 1 is a very small value.

\section{Data}

The research was conducted based on the dataset on yearly bilateral foreign direct investment flows on 72 countries-recipients of FDI and 112 countries-exporters of FDI from 2001 to 2016 . The source for 
FDI data is the database of Coordinated Direct Investment Survey provided by the International Monetary Fund. As the sources of data, the databases of the World Bank and the PRS-Group were used. The CEPII data set was used for distance (Mayer and Zignago, 2011). According to estimations of Mayer and Zignago, this variable considers distance between capitals of country pairs in kilometers. The initial specification of the model is the following:

$$
\begin{gathered}
\mathrm{FDI}_{\mathrm{ijt}}=\exp \left(\beta_{1} \operatorname{lngdpIMP}_{\mathrm{it}}+\beta_{2} \operatorname{lngdpEXP}_{\mathrm{it}}+\beta_{3} \text { Indist }_{\mathrm{ij}}+\beta_{4} \text { Openness }_{\mathrm{it}}\right. \\
\left.+\beta_{5} \text { lnremoteIMP }_{\mathrm{it}}+\beta_{6} \text { lnremoteEXP }_{\mathrm{it}}+\beta_{7} \text { Inf }_{\mathrm{it}}+\beta_{8} \text { Inst }_{\mathrm{it}}\right)+\varepsilon_{\mathrm{ij}}
\end{gathered}
$$

The dependent variable is foreign direct investment inflow from country $\mathrm{j}$ to country $\mathrm{i}$ in the period $\mathrm{t}$. Since our research is based on the gravity approach, three gravity variables were included: lngdpIMP ${ }_{\text {it }}$ is logarithm of gross domestic product (GDP) of country-importer of FDI, lngdpEXP ${ }_{\text {it }}$ is logarithm of GDP of country-exporter of FDI and lndist it is distance between FDI-importer and FDI-exporter. As control variables we add Openness $s_{i t}$, which indicates amount of trade as percent of GDP, inflation $\left(\operatorname{Inf}_{\mathrm{it}}\right)$, remoteness of FDI-importer from all other exporters - lnremoteIMP ${ }_{\text {it }}$ and remoteness of FDIexporter from all other importers (lnremoteEXP $\mathrm{it}_{\mathrm{it}}$ ). As Inst $_{\mathrm{it}}$ a vector of institutional variables is indicated.

It is considered, that remoteness of exporter and importer affects bilateral FDI flows (Mariev O., 2016). These two factors are calculated based on the World Bank database and CEPII data (Mayer, $2011)^{5}$.

As it is mentioned above, six indexes for institutions estimated by the PRS-Group are used in our research. The "Violence and Accountability" (VA) index indicates implementation military in politics and democratic accountability. "Political Stability and Absence of Violence" (PV) indicates government stability, amount of internal and external conflicts and ethnic tensions. "Government Effectiveness" (GE) is for bureaucratic quality, "Regulatory Quality" (RQ) indicates the quality of external policy including activity of foreign investors. And the last two indexes are "Rule of Law" (RL) and "Control of Corruption" (CC), which indicate the quality of the legislation system in the country. All of the indexes take the value from 0 to 1 , where " 0 " indicates low institution quality and "1" indicates high institution quality.

The main hypothesis of the research is that institutional factors have positive and significant impact on bilateral FDI flows.

As it is discussed in previous research, it must be considered that institutional indicators are highly correlated with each other. According to the correlation matrix (see Annex, Table 1) this presumption is confirmed. Thus, there is no point in including all the institutional indicators into one regression that is why at first we include institutions one by one. From the other point of view, in using such a method there is the possibility to miss an aggregate effect for the institutions. For this purpose we join the institutions by pairs into three new indicators: "Political Stability", which includes the two first indexes, "Government regulation" to which we add regulatory quality and "Legislation System" that includes the two last indexes and includes them one by one into our regression.

Our second hypothesis is that institutions have different impacts for developed and developing countries. It is considered that in developed economies institutions are highly developed and investors take into consideration other factors. However, in developing economies investors are aware of lower institutional development and less security of their rights. Thus, for developing economies institutional factors have to be more significant. For that purpose we divide our database into two groups of FDIimporters: developed and developing and put 36 countries into each group. Then we apply the similar mechanism: PPML regression on FDI and FDI+1.

\section{Results and Discussion}

As it is mentioned above, first we run a PPML regression for all countries. The number of observations in such case is only 29890 compared to 129024 in the whole database. This arises because of the existence of negative and zero values of dependent variable FDI and the main disadvantage of PPML method since it accounts only for positive values. The loss of more than half of observations leads to distortion of the results and estimation bias. Therefore we generate a new

\footnotetext{
${ }^{5}$ for additional information see Mariev, 2016.
} 
variable FDI+1, which solves the problem of zero observations. Thus, the amount of observations in regression for FDI+1 account to 112113 , which is $87 \%$ of the dataset.

The results of these two regressions confirm the assumptions of the gravity model: the GDP of the host economy and the GDP of the home economy of the FDI in most cases have significant positive impact on bilateral FDI flows. Distance between the countries negatively affects foreign direct investment inflows. By adding institutional variables the results show that all institutions have positive impact on the foreign direct investment, which confirms our general hypothesis. However, in the regression for FDI regulatory quality and government regulation were not significant. In the regression for FDI+1 all institutions have positive impact at the 1\% significance level, except regulatory quality, which is significant at the $5 \%$ significance level.

Our next step is to provide the analysis for two groups of FDI importers. For this purpose we divide the countries by level of development according to UNCTAD classification (UNCTAD, 2018). As a result, we get a group of developed economies (36 countries-importers of FDI) and a group of developing including transition economies (36 countries). Both cases have 64512 observations, but taking into consideration the problem of zero and negative observations, by applying PPML regression for dependent variable FDI, only 16979 observations are left (only $26 \%$ of the dataset). Thus, it has to be considered that such analysis distorts the results of estimation. Still the analysis approves gravity assumptions. It has to be mentioned, that adding of all institutional factors into a common regression would lead to multicollinearity and estimation bias. Therefore, we include each indicator one-by one. The results are provided in Table 1. Column (1) shows the results for the regression with an institutional factor Voice and Accountability, column (2) provides the results for Political Stability and Absence of Violence and so on. Columns (1)-(6) show results for pure PRS indexes. Still, by introducing only one indicator into the regression, a common effect could be lost. Therefore, we generate 3 new indexes from the existing 6 by finding the mean value. So, "Political Stability" considers Voice and Accountability and Political Stability and Absence of Violence, "Government Regulation" considers Government effectiveness and Regulatory Quality. The indicator "Legislation System" consists of the Rule of Law and Control of Corruption. The results are presented in columns (7)-(9).

As it is shown in Table 1, institutions have positive impacts on foreign direct investment inflows to developed economies, but we did not get any result for "Voice and accountability". This resulted because most of the developed economies a have value of "1" for this indicator. Political stability and absence of violence is significant only at the 5\% significance level. Corruption and legislation system appeared to be insignificant, while other variables were significant at the $1 \%$ level. After generating the FDI+1 variable, the estimation result of institutions have changed, first of all due to an increase in the observation amount, which was accounted to 53181 .

According to the estimation results, all institutional indicators except Political stability and absence of violence have positive and significant impact on the foreign direct investment inflows. It can be explained that countries with higher institutional development increase the amount of FDI inflows. However, the significance of the estimations tends to reject a hypothesis that institutions in developed countries are less important.

The similar analysis was provided for developing economies. Analysis of dependent variable FDI showed that political stability and absence of violence and voice and accountability are not significant. Government effectiveness is significant at the $10 \%$ significance level. Other institutional indicators were not significant. Considering the problem of PPML regression accounting for positive values, we ran the regression for the FDI+1 dependent variable. The results reject our second hypothesis that institutions in developing countries are more significant than in developed ones. According to the estimation results, only Rule of Law and Political stability and Legislation system are significant at the $10 \%$ level. Government effectiveness, Regulatory quality and Government Regulation are significant at the 5\% significance level. Other institutional variables appeared to be insignificant. This can be explained by the low development of institutions in developing economies, which allows proposing that other factors can be more applicable to explain foreign direct investment flows. However, all institutional variables have positive effect of institutions on foreign direct investment inflows, so improvement of institutional environment in developing countries could attract more FDI. The results are provided in Table 2. 


\begin{tabular}{|c|c|c|c|c|c|c|c|c|c|}
\hline & \multicolumn{9}{|c|}{ PPML (FDI+1) } \\
\hline FDI & (1) & (2) & (3) & (4) & \begin{tabular}{|l|} 
(5) \\
\end{tabular} & (6) & (7) & (8) & (9) \\
\hline $\begin{array}{l}\text { GDP of country- } \\
\text { importer of FDI }\end{array}$ & $3.88^{* * *}$ & $2.295 * * *$ & $2.631 * * *$ & $2.471 * * *$ & $3.534 * * *$ & $36.348 * * *$ & $2.371 * * *$ & $2.449 * * *$ & 80.186 *** \\
\hline $\begin{array}{l}\text { GDP of country- } \\
\text { exporter of FDI }\end{array}$ & $0.417 * * *$ & $0.344 * * *$ & $0.453 * * *$ & $0.324 * * *$ & $0.427 * * *$ & $0.346^{* * *}$ & $0.407 * * *$ & $0.393 * * *$ & $2.171 * * *$ \\
\hline $\begin{array}{l}\text { Remoteness of } \\
\text { importer }\end{array}$ & $3.959 * * *$ & $10.349 * * *$ & 8.983 *** & 16.382 *** & $3.617 * * *$ & 74.986 *** & 0.548 & $9.149 * * *$ & $33.788 * * *$ \\
\hline $\begin{array}{l}\text { Remoteness of } \\
\text { exporter }\end{array}$ & -23.288 **** & $-20.465^{* * *}$ & - $20.347 * * *$ & $-22.99 * * *$ & $-22.881 * * *$ & $-\overline{104.942 * * *}$ & 20.571*** & $-\overline{19.258 * * *}$ & $\begin{array}{l}- \\
370.747 * * *\end{array}$ \\
\hline Openness & 0.001 & 0.012 **** & 0.007 *** & \begin{tabular}{|l}
$0.015 * * * *$ \\
\end{tabular} & $\begin{array}{l}-0.003 * \\
\end{array}$ & $0.012 * *$ & -0.006 **** & 0.007 **** & $-0.017 * *$ \\
\hline Distance & -0.373 & $\begin{array}{l}-0.099 \\
\end{array}$ & $-0.503 * *$ & \begin{tabular}{|l|}
-0.081 \\
\end{tabular} & $-0.404 * *$ & -0.35 & $-0.327 * *$ & -0.287 **** & $-1.47 * *$ \\
\hline Inflation & $-1.211 * * *$ & $-0.525 * * *$ & $-0.718 * * *$ & -0.608 **** & $-1.15 * * *$ & $-17.201 * * *$ & $-0.753 * * *$ & -0.606 *** & $-37.243 * * *$ \\
\hline $\begin{array}{l}\text { Voice and } \\
\text { Accountability }\end{array}$ & $256.006 * * *$ & (1) & 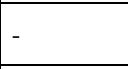 & (1) & - & - & - & - & - \\
\hline $\begin{array}{l}\text { Political Stability } \\
\text { and Absence of } \\
\text { Violence }\end{array}$ & - & 0.117 & - & - & - & - & - & - & - \\
\hline $\begin{array}{l}\text { Government } \\
\text { Effectiveness }\end{array}$ & - & - & $94.113 * * *$ & - & - & - & - & - & - \\
\hline Regulatory Quality & - & - & - & $7.071 * * * *$ & - & - & - & - & - \\
\hline Rule of Law & - & - & - & - & $143.189^{* * * *}$ & - & - & - & - \\
\hline $\begin{array}{l}\text { Control of } \\
\text { Corruption }\end{array}$ & - & - & - & - & - & $288.442 * * *$ & - & - & - \\
\hline Political Stability & - & - & - & - & - & - & 20.034 *** & - & - \\
\hline $\begin{array}{l}\text { Government } \\
\text { regulation }\end{array}$ & - & - & - & - & - & - & - & $7.278 * * *$ & - \\
\hline Legislation System & - & - & - & - & - & - & - & - & $1264.74 * * * *$ \\
\hline Constant & 20.486 & 317.265 & 216.046 & 400.19 & 88.702 & 1744.78 & 207.078 & 292.107 & 2661.248 \\
\hline $\begin{array}{l}\text { Number of } \\
\text { observations }\end{array}$ & 53181 & 53181 & 53181 & 53181 & 53181 & 53181 & 53181 & 53181 & 53181 \\
\hline
\end{tabular}

Note: $* * *$ indicates $1 \%$ significance level, $* * 5 \%$ significance level, * 10\% significance level

Source: Author

Table 2: Regression results for developing countries for dependent variable FDI+1

\begin{tabular}{|c|c|c|c|c|c|c|c|c|c|}
\hline & \multicolumn{9}{|c|}{ PPML (FDI+1) } \\
\hline FDI & (1) & (2) & (3) & (4) & (5) & (6) & (7) & (8) & (9) \\
\hline GDP of country-importer of FDI & $0.905 * * *$ & $0.91 * * *$ & $0.915 * * *$ & $0.906 * * *$ & $0.914 * * *$ & $0.914 * * *$ & $0.893 * * *$ & $0.909 * * *$ & $0.916^{* * *}$ \\
\hline GDP of country-exporter of FDI & $0.314 * * *$ & $0.312 * * *$ & $0.315 * * *$ & $0.315 * * *$ & $0.314 * * *$ & $0.315 * * *$ & $0.314 * * *$ & $0.314 * * *$ & $0.314 * * *$ \\
\hline Remoteness of importer & $1.691 * * *$ & $1.829 * * *$ & $1.753 * * *$ & $1.651 * * *$ & $1.49 * * *$ & $1.752 * * *$ & $1.822 * * *$ & $1.721 * * *$ & $1.644 * * *$ \\
\hline Remoteness of exporter & $0.38 *$ & $0.367 *$ & $0.38^{*}$ & $0.379 *$ & $0.374^{*}$ & $0.377^{*}$ & $0.374 *$ & $0.378^{*}$ & $0.373^{*}$ \\
\hline Openness & 0.006 *** & $0.007 * * *$ & $0.006^{* * * *}$ & $0.006^{* * *}$ & $0.007 * * *$ & $0.007 * * *$ & $0.006^{* * *}$ & $0.007 * * *$ & $0.007 * * *$ \\
\hline Distance & $-\overline{0.273 * * *}$ & $-\overline{0.274 * * *}$ & $0.274 * * *$ & $-273 * * *$ & $-\overline{0.277 * * *}$ & $0.274 * * *$ & $-\overline{0.272 * * *}$ & $-\overline{0.274 * * *}$ & $-{ }_{0.276^{* * *}}$ \\
\hline Inflation & $-0.050 * * *$ & $-0.064 * * *$ & $0.054 * * *$ & $-0.053 * * *$ & $-0.06 * * *$ & $-0.052 * * *$ & $-0.51 * * *$ & $-0.054 * * *$ & $-0.057 * * *$ \\
\hline Voice and Accountability & 0.184 & - & - & - & - & - & - & - & - \\
\hline $\begin{array}{l}\text { Political Stability and Absence of } \\
\text { Violence }\end{array}$ & - & 1.421 & - & - & - & - & - & - & - \\
\hline Government Effectiveness & - & - & $0.277 * *$ & - & - & - & - & - & - \\
\hline Regulatory Quality & - & - & - & $-0.218 * *$ & - & - & - & - & - \\
\hline Rule of Law & - & - & - & - & $0.596^{*}$ & - & - & - & - \\
\hline Control of Corruption & - & - & - & - & - & 0.394 & - & - & - \\
\hline Political Stability & - & - & - & - & - & - & $0.999^{*}$ & - & - \\
\hline Government regulation & - & - & - & - & - & - & - & $0.378^{* *}$ & - \\
\hline Legislation System & - & - & - & - & - & - & - & - & $0.763^{*}$ \\
\hline Constant & -26.892 & -27.191 & -27.555 & -26.499 & -24.839 & -27.523 & -27.343 & -27.095 & -26.28 \\
\hline Number of observations & 58932 & 58932 & 58932 & 58932 & 58932 & 58932 & 58932 & 58932 & 58932 \\
\hline
\end{tabular}

\section{Conclusion}

The results obtained during the research confirm that various institutional determinants have a positive impact on foreign direct investment inflows. However, the significance of this impact is considered to be different for developed and developing economies. According to the provided research institutions, developing economies have positive but less significant impact than developed economies. Therefore, it can be concluded that development of institutions can further increase the amount of foreign direct investment inflows. The assumptions of the gravity approach considered in the paper were approved. The size of the economies has a positive impact on foreign direct investment attraction and distance between them negatively affects the FDI inflows. In addition, such indicators such as openness, 
remoteness and distance appeared to have more significant impact on FDI inflows for developing economies. Still by using the PPML method there are a number of observations omitted because of the negative FDI values, thus there is a direction for further research on the topic.

\section{Acknowledgements}

This research was supported by the President of Russia grant "Institutional determinants of foreign direct investment inflows: country and region level analysis " (grant No. MD-6402.2018.6).

\section{References}

Ali, F., Fiess N., MacDonald, R. (2010). Do Institutions Matter for Foreign Direct Investment? Open Economics Review, 21 (2), 201-219. https://dx.doi.org/10.1007/s11079-010-9170-4

Bailey, N. (2018). Exploring the relationship between institutional factors and FDI attractiveness: A meta-analytic review. International Business Review, 27 (1), 139-148. https://dx.doi.org/10.1016/j.ibusrev.2017.05.012

Benassy-Quere, A., Couper, M., Mayer, T. (2007). Institutional Determinants of Foreign Direct Investment. The World Economy, 30 (5), 764-782. https://dx.doi.org/10.1111/j.1467-9701.2007.01022.x

Bevan, A., Estrin, S., Meyer, K. (2004) Foreign investment location and institutional development in transition economies. International Business Review, 13 (1), 43-64. https://dx.doi.org/10.1016/j.ibusrev.2003.05.005

Brunetti, A., Weder, B. (1998). Investment and Institutional Uncertainty: A comparative Study of Uncertainty Measures. Review of World Economics, 134 (3), 513-533. https://dx.doi.org/10.1007/BF02707928

Busse, M., Hefker, C. (2007). Political Risk, Institutions and Foreign Direct Investment. European Journal of Political Economy, 23(2), 397-415. https://dx.doi.org/10.1016/j.ejpoleco.2006.02.003

Daude, Ch., Stein, E. (2007, February). The Quality of Institutions and Foreign Direct Investment. Economics and Politics, 19 (3), 317-344. https://dx.doi.org/10.1111/j.1468-0343.2007.00318.x

International Monetary Fund (2018). Coordnated Direct Investment Survey (CDIS). Retrieved from: http://data.imf.org/?sk=40313609-F037-48C1-84B1-E1F1CE54D6D5

Knack, S., Keefer, P. (1995). Institutions and Economic Performance: Cross-Country Tests Using Alternative Institutional Measures. Economics and Politics, 7(3), 207-227. https://dx.doi.org/10.1111/j.1468-0343.1995.tb00111.x

Kolstad, I., Tondel, L. (2002) Social Development and Foreign Investments in Developing Countries. Research report, 11, Chr. Michelsen Institute, 1-34.

Mariev O., Drapkin I., Chukavina K. (2016) Is Russia successful in attracting foreign direct investment? Evidence based on gravity model estimation. Review Of Economic Perspectives. 16(3), 245-267. https://dx.doi.org/10.1515/revecp-2016-0015

Mayer, T., Zignago, S. (2011, December). Notes on CEPII's distances measures: The GeoDist database. CEPII Working Papers, 2011-25. Retrieved from http://www.cepii.fr/CEPII/en/publications/wp/abstract.asp?NoDoc=3877

Peres, M., Ameer, W., Xu H. (2018) The impact of institutional quality on foreign direct investment inflows: evidence for developed and developing countries. Economic Research-Ekonomska Istraživanja. 31(1), 626-644. https://dx.doi.org/10.1080/1331677X.2018.1438906

Silva S., Tenreyro, S. (2006) The Log of Gravity. The Review of Economics and Statistics. 88(4), 641-658. https://dx.doi.org/10.1162/rest.88.4.641

Tintin C. (2013) The determinants of foreign direct investment inflows in the Central and Eastern European Countries: The importance of institutions. Communist and Post-Communist Studies. 46, pp. 287-298.

https://dx.doi.org/10.1016/j.postcomstud.2013.03.006

The PRS Group (2018). International Country Risk Guide Methodology. Retrieved from: https://www.prsgroup.com/wpcontent/uploads/2012/11/icrgmethodology.pdf

The UNCTAD (2018). Country Classifications. Development status groups and composition. Retrieved from: https://unctadstat.unctad.org/en/Classifications/DimCountries_DevelopmentStatus_Hierarchy.pdf

The World Bank Group (2018) The World Bank Database: World Development Indicators. Retrieved from: https://databank.worldbank.org/data/indicator/NY.GDP.MKTP.CD/1ff4a498/Popular-Indicators

The World Bank Group (2018) Political Risk Services International Country Risk Guide. Retrieved from: https://info.worldbank.org/governance/wgi/pdf/prs.xlsx 